\title{
Characterization of Mycobacterium tuberculosis LexA: recognition of a Cheo (Bacillus-type SOS) box
}

\author{
Farahnaz Movahedzadeh, M. Joseph Colston and Elaine O. Davis
}

Author for correspondence: Elaine O. Davis. Tel: +44 181959 3666. Fax : +441819138528. e-mail: e-davis@nimr.mrc.ac.uk

Division of Mycobacterial Research, National Institute for Medical Research, Mill Hill, London NW7 1AA, UK

\begin{abstract}
The gene coding for the Mycobacterium tuberculosis homologue of LexA has been cloned and sequenced. Amino acids required for autocatalytic cleavage are conserved, whereas those important for specific DNA binding are not, when compared with Escherichia coli LexA. The transcriptional start site was mapped and a DNA sequence motif was identified which resembled the consensus Cheo box sequence involved in the regulation of DNA-damageinducible genes in Bacillus subtilis. The $M$. tuberculosis LexA protein was overexpressed in $E$. coli and purified by means of a His tag. The purifed LexA was shown to bind to the Cheo box sequence found upstream of its own gene.
\end{abstract}

Keywords: Mycobacterium tuberculosis, LexA, RecA, DNA-damage-inducible genes, DNA-binding protein

\section{INTRODUCTION}

The Gram-positive bacterium Mycobacterium tuberculosis is the causative agent of tuberculosis, a disease which is responsible for more deaths worldwide than any other single infectious agent (Kochi, 1991). M. tuberculosis is an intracellular pathogen which survives and replicates in macrophages, part of the normal host defence mechanism. In this environment the bacteria would be exposed to conditions such as hydrogen peroxide and reactive nitrogen intermediates which would be expected to lead to DNA damage. Therefore, the response of $M$. tuberculosis to DNA damage could be important in pathogenesis.

Bacterial responses to DNA damage are highly conserved (Walker, 1984), in particular the RecA protein, which also has a central role in recombination (Miller $\&$ Kokjohn, 1990). In the SOS response of Escherichia coli a group of over 20 genes is induced by a common regulatory mechanism in which RecA and LexA are the key players. This leads to increased synthesis of proteins involved in DNA repair, DNA synthesis, homologous and site-specific recombination and cell division, leading to an increase in cell survival.

Under normal conditions LexA binds to a specific DNA sequence, the SOS box, upstream of the genes it regulates, and represses transcription (Little \& Mount,

The EMBL accession number for the sequence reported in this paper is X91407.
1982). Exposure to DNA damage activates RecA coprotease activity, which then triggers the autocatalytic cleavage of LexA (Little, 1984, 1991), resulting in its release from its binding sites and increased expression of the genes it regulates, including $r e c A$ and $\operatorname{lex} A$ themselves (Little et al., 1994). The sequence of the SOS box (consensus taCTGTatatananaCAGta: Walker, 1984) is conserved amongst most Gram-negative bacteria, but a different sequence is found upstream of DNA-damageinducible genes in the Gram-positive bacterium Bacillus subtilis, termed the Cheo box [consensus GAACNNNNGTTC, Cheo et al. (1991)]. The recA genes of $M$. tuberculosis and $M$. leprae have been cloned and sequenced (Davis et al., 1991, 1994) and in both cases a sequence identical to the Cheo box consensus has been identified in the upstream regions. In order to determine whether this is the site to which LexA binds in mycobacteria, a source of pure mycobacterial LexA protein was required for in vitro binding assays. Towards this end, we now report the cloning, sequencing, expression and purification of $M$. tuberculosis LexA, and show that it does indeed bind to a Cheo box discovered in its own promoter region.

\section{METHODS}

Bacterial strains, plasmids and growth conditions. Escherichia coli strain DH5 $\alpha$ (Sambrook et al., 1989) was used for all plasmid constructions and strain BL21(DE3)pLysS (Studier et al., 1990) was used for expression of LexA from the T7 promoter. The plasmid vectors used in this study are listed 
Table 1. Plasmids used in this study

\begin{tabular}{|c|c|}
\hline Plasmid & Relevant characteristics or reference \\
\hline pFM8 & $1.3 \mathrm{~kb}$ Sall fragment of M. tuberculosis lexA gene in SalI site of pUC19 \\
\hline pFM9 & $1.5 \mathrm{~kb} S m a \mathrm{I}$ fragment of M. tuberculosis lexA gene in SmaI site of pUC19 \\
\hline pFM14 & $0.7 \mathrm{~kb}$ AfliII-SmaI fragment of pFM9 in SmaI site of pTZ18R \\
\hline pFM16 & $1 \cdot 3 \mathrm{~kb}$ Sall fragment of $\mathrm{pFM} 8$ in $3 \mathrm{~kb}$ Sall fragment of $\mathrm{pFM} 14$ \\
\hline pFM18 & $0.65 \mathrm{~kb} N d e \mathrm{I}-\mathrm{BamHI}$ fragment of PCR product of $l e x A$ gene from pFM16 in NdeI-BamHI site of pET-15b \\
\hline pTZ18R & Mead et al. (1987) \\
\hline pUC19 & Yanisch-Perron et al. (1985) \\
\hline pET-15b & Studier et al. (1990) \\
\hline
\end{tabular}

in Table 1. E. coli cultures were grown at $37^{\circ} \mathrm{C}$ in $\mathrm{LB}$ medium (Sambrook et al., 1989) with the addition of ampicillin and methicillin, where appropriate, at $50 \mu \mathrm{g} \mathrm{ml}^{-1}$ each. $M$. tuberculosis was grown in modified Dubos medium (Difco) at $37^{\circ} \mathrm{C}$.

Recombinant DNA techniques. Standard molecular and recombinant DNA techniques were used (Sambrook et al., 1989). Plasmid minipreps were prepared by the boiling method (Holmes \& Quigley, 1981) or using a Qiagen miniprep kit. Maxipreps were prepared using the Qiagen plasmid/cosmid purification kit. DNA was digested with restriction enzymes (New England Biolabs and Life Technologies) according to the manufacturers' instructions. DNA fragments were purified from agarose gels using Geneclean (Bio 101).

Southern hybridizations. DNA fragments for use as probes were labelled by random primer extension with the ECL DNA labelling kit (Amersham) following the manufacturer's instructions. Hybridization was performed using Hybond-N membranes (Amersham) at $60^{\circ} \mathrm{C}$ overnight prior to washing twice for $30 \mathrm{~min}$ at $60^{\circ} \mathrm{C}$ with $2 \times \mathrm{SSC} / 0 \cdot 1 \%$ SDS. Then blocking, antibody incubation and washing steps were performed following the manufacturer's instructions.

DNA sequencing and analysis. Sequencing was performed using a Sequenase kit (USB/Amersham) with the inclusion of $E$. coli single-strand-binding protein in the reactions using both universal and specific primers. The reactions were resolved on $6 \%(\mathrm{w} / \mathrm{v})$ polyacrylamide gels, and the sequences compiled and analysed using the Lasergene (DNAStar) and GCG (Devereux et al., 1984) programs.

Preparation of $\boldsymbol{M}$. tuberculosis RNA. RNA was isolated as described by Gonzalez-y-Merchand et al. (1996).

Primer extension reactions. The oligonucleotide primers were end-labelled with $\left[\gamma^{-32} \mathrm{P}\right]$ ATP at their $5^{\prime}$ termini by means of $\mathrm{T} 4$ polynucleotide kinase as described in the primer extension kit (Promega). Labelled primer (1 pmol) was annealed to $40 \mu \mathrm{g}$ total RNA at $52^{\circ} \mathrm{C}$ (based on the melting temperature of the primer being used) for $1 \mathrm{~h}$. Extension was carried out using AMV reverse transcriptase (Promega), according to the manufacturer's instructions, at $42^{\circ} \mathrm{C}$ for $1 \mathrm{~h}$. The products were ethanol precipitated, resuspended in $5 \mu \mathrm{l}$ Tris/EDTA pH 7.5 plus $5 \mu \mathrm{l}$ loading dye $[98 \%(\mathrm{v} / \mathrm{v})$ formamide, $10 \mathrm{mM}$ EDTA, $0.1 \%$ xylene cyanol, $0 \cdot 1 \%$ bromophenol blue] and denatured at $90^{\circ} \mathrm{C}$ for $10 \mathrm{~min}$ before being separated on an $8 \%(\mathrm{w} / \mathrm{v})$ polyacrylamide-urea gel.

Overexpression of $\boldsymbol{M}$. tuberculosis LexA. The coding sequence for LexA was amplified by PCR using primers designed with the aid of the program PrimerSelect (DNAStar) to introduce restriction sites for $\mathrm{NdeI}$ at the $\mathrm{N}$ terminus and $\mathrm{BamHI}$ at the $\mathrm{C}$ terminus to permit cloning in-frame into the expression vector $\mathrm{pET}-15 \mathrm{~b}$ (Novagen). The primers used (each at $300 \mathrm{nM}$ final concentration) were GGAACCTCAT ATGTTGTCCGCAGATTC and GGGATCCTCAGACCTTCCGTATCACCGT. The introduced restriction site is in bold and the start and stop codons are indicated by italics. PCR was performed using Expand High Fidelity PCR system (Boehringer Mannheim) with pFM16 (15 ng) as template. The temperature cycle used was as follows: an initial $5 \mathrm{~min}$ at $94^{\circ} \mathrm{C}$ to denature high G + C DNA; then 10 cycles of $30 \mathrm{~s}$ at $94^{\circ} \mathrm{C}, 30 \mathrm{~s}$ at $37^{\circ} \mathrm{C}$ and $1.5 \mathrm{~min}$ at $72^{\circ} \mathrm{C}$; then $20 \mathrm{cycles}$ of $30 \mathrm{~s}$ at $94^{\circ} \mathrm{C}, 30 \mathrm{~s}$ at $37^{\circ} \mathrm{C}$ and 1.5 min plus $20 \mathrm{~s}$ per cycle at $72^{\circ} \mathrm{C}$; and finally a last extension step of $72^{\circ} \mathrm{C}$ for $7 \mathrm{~min}$ to complete primer extension. The annealing was done at a low temperature due to mismatches incorporated into the primers to prevent dimer formation.

The resulting PCR product was digested with NdeI and BamHI and cloned into pET-15b to give pFM18. This clone was transformed into E. coli BL21(DE3)pLysS. Cultures were grown in LB broth containing $200 \mu \mathrm{g}$ ampicillin $\mathrm{ml}^{-1}$ and $34 \mu \mathrm{g}$ chloramphenicol ml ${ }^{-1}$, and were induced at $\mathrm{OD}_{600} 0.5(1 \mathrm{~cm}$ pathlength, Unicam UV2 spectrometer) by the addition of IPTG to a final concentration of $0 \cdot 1 \mathrm{mM}$ (along with more ampicillin to $200 \mu \mathrm{g} \mathrm{ml}^{-1}$ ) and incubation continued for a further $3 \mathrm{~h}$ before harvesting.

Purification of $\boldsymbol{M}$. tuberculosis LexA. The induced cells were harvested, resuspended in sonication buffer $(50 \mathrm{mM}$ phosphate $\mathrm{pH} 8,1 \mathrm{M} \mathrm{NaCl}$ ), and lysed by sonication at $100 \mathrm{~W}$ for $4 \times 30 \mathrm{~s}$. The LexA protein was purified by means of the His tag introduced from the vector on a Ni-NTA (Qiagen) column. The lysate was applied at $1 \mathrm{ml} \mathrm{min}{ }^{-1}$, the column washed with $50 \mathrm{mM}$ phosphate $\mathrm{pH} 5,1 \mathrm{mM}$ imidazole, $10 \%$ (w/v) glycerol, and the LexA protein eluted with $50 \mathrm{mM}$ phosphate pH $8,1 \mathrm{M} \mathrm{NaCl}, 0.25 \mathrm{M}$ imidazole. The purified protein was estimated by SDS-PAGE to be $>95 \%$ pure.

Gel retardation assays. Gel shift assays were carried out using a DIG gel shift kit (Boehringer Mannheim). The doublestranded oligonucleotide $\left(3-4 \mathrm{pmol}^{-1} \mathrm{l}^{-1}\right.$ ) was labelled following the manufacturer's instructions, then diluted to a concentration of $15-30 \mathrm{fmol}^{l^{-1}}$ in TEN buffer $(10 \mathrm{mM}$ Tris/HCl, $1 \mathrm{mM}$ EDTA, $0 \cdot 1 \mathrm{M} \mathrm{NaCl}, \mathrm{pH}$ 8). The gel shift reaction was set up according to the manufacturer's instructions using $0 \cdot 1 \mu \mathrm{g}$ LexA protein with poly[d(I-C)] competitor DNA. Following incubation at room temperature for $15 \mathrm{~min}$, the sample was applied immediately to a pre-electrophoresed native $8 \%(\mathrm{w} / \mathrm{v})$ polyacrylamide gel. The gel system used was a Maxigel (Biometra) which has gel dimensions of $20 \mathrm{~cm} \times 20$ $\mathrm{cm} \times 1 \mathrm{~mm}$ thick. Electrophoresis was carried out in $0.5 \times \mathrm{TBE}$ 


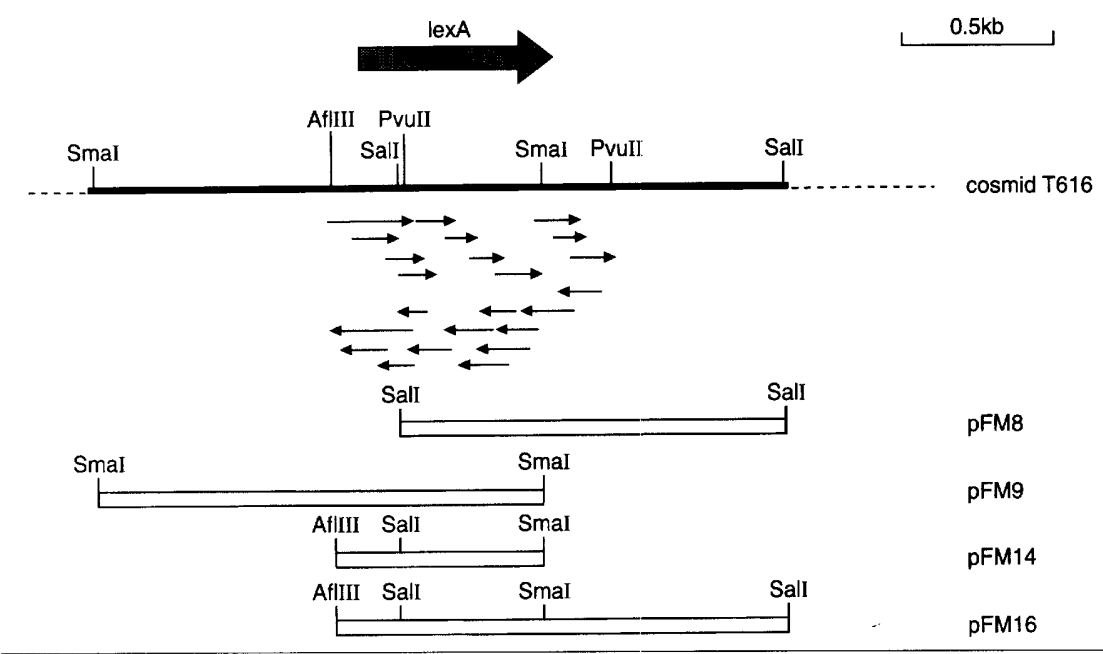

Fig. 1. Restriction map and sequencing
strategy of $M$. tuberculosis lexA. Relevant
restriction sites are marked, and the location
and direction of transcription of lexA are
indicated by the large arrow above the map.
The small arrows below the map represent
the sequencing strategy, with arrowheads
indicating the direction of sequencing. The
fragments contained in the various clones
described in the text are indicated by the
bars.

buffer $\mathrm{pH} 8$, at $160 \mathrm{~V}$ at $4^{\circ} \mathrm{C}$ in a cold room. One lane was loaded with sample buffer containing bromophenol blue to follow the extent of electrophoresis; the dye was run threequarters of the way to the bottom of the gel. The gel was blotted onto a positively charged BM nylon membrane (Boehringer Mannheim) using a Semi-Dry Electroblotter (Ancos) at $400 \mathrm{~mA}$ for $1 \mathrm{~h}$. Then the membrane was soaked in $10 \times \mathrm{SSC}$ for $30 \mathrm{~s}$ and cross-linked for $1 \mathrm{~min}$ at $300 \mathrm{~nm}$ with a transilluminator. The chemiluminescent detection was performed following the manufacturer's instructions. The membrane was exposed to X-ray film (Hyperfilm-MP, Amersham) for $15-40 \mathrm{~min}$ at room temperature.

\section{RESULTS}

\section{Cloning the $M$. tuberculosis lexA gene}

The lexA gene of M. tuberculosis had been located on cosmids T31, T616 and T754 (Philipp et al., 1996) as part of the $M$. tuberculosis genome analysis project. A $400 \mathrm{bp}$ lexA probe made by PCR from total $M$. tuberculosis DNA was used in hybridizations to cosmid T616 (both probe and clone were kindly provided by Dr S. T. Cole, Institut Pasteur, Paris, France) digested with various restriction enzymes to identify restriction fragments suitable for subcloning. A $1.3 \mathrm{~kb}$ SalI and a $1.5 \mathrm{~kb}$ Smal fragment were each cloned into pUC19 to give pFM8 and pFM9, respectively (Fig. 1). Subsequent DNA sequence analysis (see below) revealed that neither of these clones contained an intact lexA gene. Therefore, overlapping fragments from the two clones pFM8 and pFM9 were cloned sequentially into pTZ18R to yield pFM16 bearing an intact lexA gene: first a $0.7 \mathrm{~kb}$ AflIII-Smal fragment was isolated from pFM9, made blunt-ended and cloned into the SmaI site of pTZ18R to give pFM14; then the $1.3 \mathrm{~kb}$ Sall fragment from $\mathrm{pFM} 8$ was cloned into SalI-digested pFM14 to give pFM16 (Fig. 1).

\section{DNA sequence analysis}

The sequence of a $907 \mathrm{bp}$ region of DNA containing lexA was determined on both strands using both universal primers with various subclones in pUC19 and some primers designed to the sequence generated; the overall sequencing strategy is shown in Fig. 1. Within this region a $651 \mathrm{bp}$ ORF coding for a protein 217 amino acids long was identified (Fig. 2). This ORF exhibited very high homology to $M$. leprae lexA $(89 \%$ identity of amino acids) and lower but still significant homology with lexA from $B$. subtilis $(47 \%$ amino acid identity, $72 \%$ similarity) and E. coli ( $36 \%$ identity, $57 \%$ similarity) (Fig. 3). The start codon for translation was presumed to be the GTG at position 107, and not the ATG at position 50, based on these alignments to give a protein of similar size to other LexA proteins, and also

\footnotetext{
1 GTOGAACACATGTTIGATTCTTGGTGCGAATGCGACTACATTCATTGCQATGAACGACAG

61 CAACGACACCTCGGTTGCCGGCGGAGCCGCTGGTGCGGACAGCCGGGTGCTGTCCGCAG $\begin{array}{llllllllllllllllllll}S & A & L & T & E & R & Q & R & T & I & L & D & V & I & R & A & S & V & T & S\end{array}$

Fig. 2. Sequence of the lexA gene of $M$. tuberculosis. The DNA sequence of the gene and flanking regions is shown, with the protein translation of LexA. The transcription initiation site is marked with a circle and the Cheo box motif is boxed. Possible promoter-like sequences are underlined and a putative ribosome-binding site is overlined. 


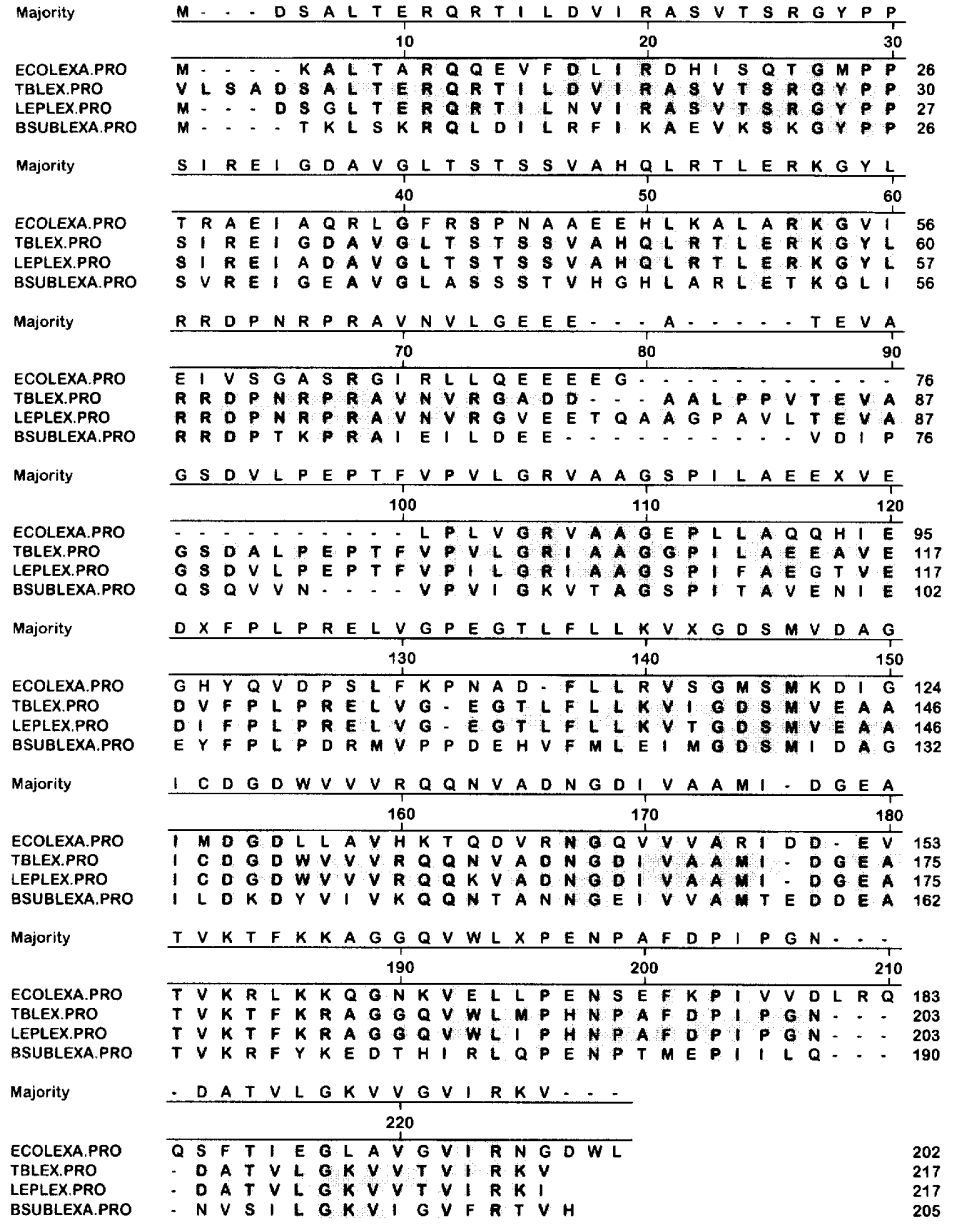

Fig. 3. Comparison of the $M$. tuberculosis LexA protein sequence with those of $M$. leprae (accession number U00019, bases 7772-8425), B. subtilis (accession number $M 64684$ ) and $E$. coli (accession number J01643). The alignment was generated by the program MegAlign (DNAStar) using the Cluster method. Residues that are identical to the $M$. tuberculosis sequence are highlighted. because of the presence of a potential ribosome-binding sequence just upstream of the GTG (Fig. 2) but not the ATG codon, and the location of the transcription start site (see below).

\section{Mapping the transcriptional start site}

The site of transcription initiation was identified by primer extension using a primer (ACGTCGAGAATAGTGCGTTG) complementary to, and close to the beginning of, the LexA coding sequence. This primer was annealed to total RNA $(40 \mu \mathrm{g})$ isolated from $M$. tuberculosis which had been cultured in the absence or presence of ofloxacin $\left(1 \mu \mathrm{g} \mathrm{ml}^{-1}\right)$ to induce SOS genes (F.M., unpublished observation) and extended with AMV reverse transcriptase as described in Methods. The transcriptional start site was found to be at an A 57 bp upstream of the GTG translational start codon (Figs 2, 4). This coincided with the ATG of the possible alternative translational start site referred to above; although there are examples of transcription and translation initiating at the same point in mycobacteria (Timm et al., 1994; Sarkis et al., 1995), these are rare, and in conjunction with the considerations discussed in the previous section it seems most likely that this is not so in this case. The transcriptional start site is preceded at an appropriate distance ( 8 bases upstream) by the sequence elements TACATT and TTGGTG which have homology with the -10 (TATAAT) and -35 (TTGACA) regions of $E$. coli promoters, respectively, but there is a spacing of only $10 \mathrm{bp}$ between these two elements in this mycobacterial promoter region instead of the 16-19 bp found for E. coli promoters (Rosenberg \& Court, 1979). It remains to be determined experimentally whether these elements constitute the binding site for mycobacterial RNA polymerase. The -35 -like sequence was 5 bp downstream from the Cheo-box-like sequence identified upstream of the lex $A$ gene (see below).

\section{High-level expression and purification of $M$. tuberculosis LexA}

Purified M. tuberculosis LexA would facilitate studies of its role in the regulation of DNA-damage-inducible genes of $M$. tuberculosis, particularly recA. Therefore, the coding sequence for LexA was amplified by PCR using primers which introduced restriction sites at appropriate locations and, after digestion, the resulting fragment was cloned into the T7 expression vector pET$15 \mathrm{~b}$ to produce a fusion protein having an N-terminal His tag (see Methods for details). Induction of this clone (pFM18) in E. coli strain BL21(DE3)pLysS gave highlevel expression of an approximately $28 \mathrm{kDa}$ protein corresponding to the LexA fusion protein, which was 


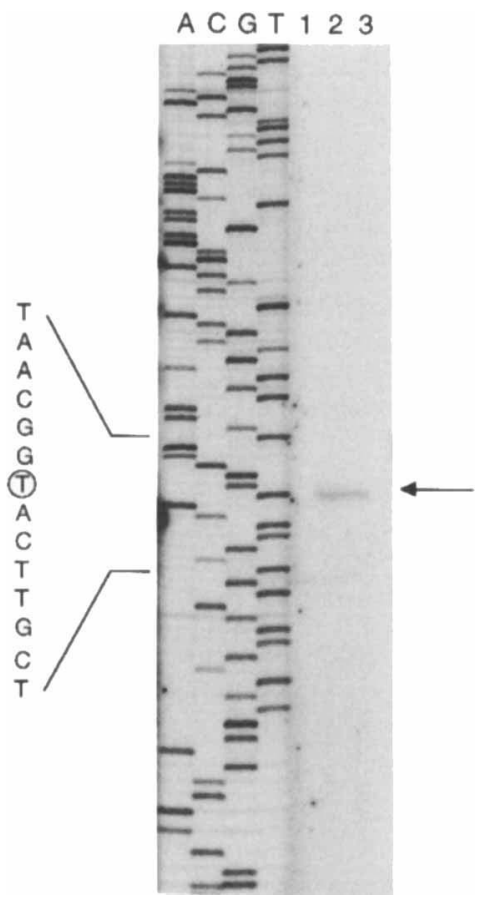

Fig. 4. Primer extension analysis. The products of primer extensions (indicated by the arrow) using a primer complementary to lexA on no RNA (lane 1), $M$. tuberculosis RNA isolated from uninduced cultures (lane 2), and $M$. tuberculosis RNA isolated from cultures induced with $1 \mu \mathrm{g}$ ofloxacin $\mathrm{ml}^{-1}$ (lane 3 ) are shown adjacent to sequencing reactions performed with the same primer (lanes A, C, G, T). The base corresponding to the deduced transcription start site is circled on the sequence given alongside.

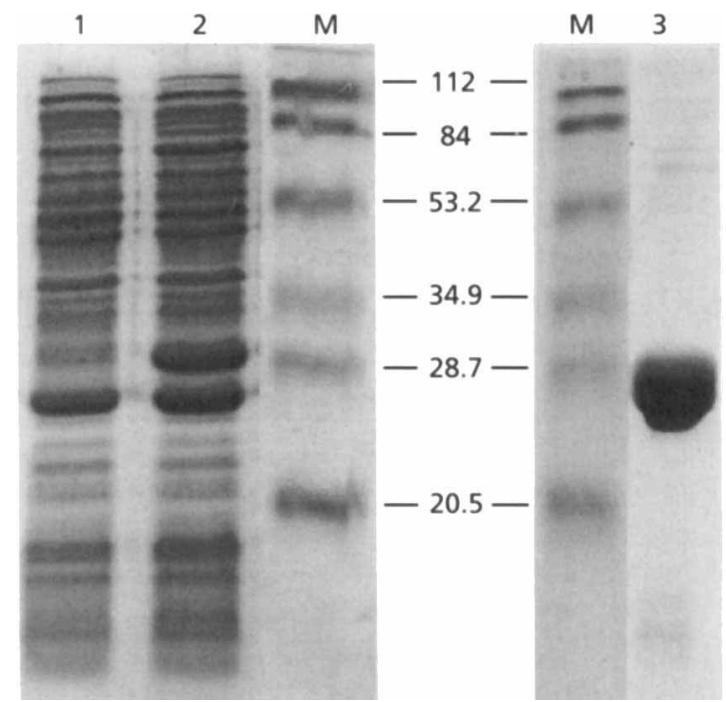

Fig. 5. Expression and purification of $M$. tuberculosis LexA: SDS-PAGE of total cell lysates from induced cultures of $E$. coli $B L 21(D E 3) p L y s S$ harbouring the vector pET-15b (lane 1) or the clone PFM18 (lane 2), and of LexA protein purified by Ni-NTA column chromatography (lane 3 ). The sizes of the molecular mass markers (lanes $M$ ) are indicated in $\mathrm{kDa}$. This figure was generated using Adobe Photoshop and Macromedia Freehand. absent from the vector control (Fig. 5a). The protein was purified on the basis of the affinity of the His tag for metal ions on a Ni-NTA column as detailed in Methods, which yielded $>95 \%$ pure LexA protein from this single step (Fig. 5b).

\section{LexA binds to the Cheo box upstream of its own gene}

Interestingly, $103 \mathrm{bp}$ upstream of the LexA coding sequence there is a motif (GAAC- $\mathrm{N}_{4}$-GTTT) (Fig. 2) similar to those found upstream of SOS-inducible genes in B. subtilis termed a Cheo box and having the consensus sequence GAAC- $\mathrm{N}_{4}$-GTTC (Cheo et al., 1991). An identical sequence to that in front of $M$. tuberculosis lexA is found in an equivalent location (100 bp upstream) with lexA from M. leprae (accession number U00019, bases 7772-8425), and a motif identical to the $B$. subtilis consensus sequence is found $121 \mathrm{bp}$ upstream of M. tuberculosis recA (Davis et al., 1991) and $111 \mathrm{bp}$ upstream of $M$. leprae recA (accession number X73822). This distribution of the motif upstream of each of the genes identified to date which would be part of the SOS response in mycobacteria suggests that, as in B. subtilis, it is involved in regulation of expression of DNA-damage-inducible genes in mycobacteria.

To test this hypothesis, the purified LexA was used in a gel retardation assay using a $32 \mathrm{bp}$ double-stranded oligonucleotide (CACGCCTGTCGAACACATGTTTGATTCTTGGT) spanning the Cheo box (in bold) identified in the DNA sequence upstream of the lexA gene (see above). Retardation of this fragment due to binding of the protein was clearly observed in the presence of LexA protein (Fig. 6, lanes 4 and 5). The proportion of retarded DNA was reduced when the reaction was performed in the presence of excess unlabelled oligonucleotide of the same sequence (Fig. 6, lane 6). In contrast, no retardation was observed when LexA was incubated with a $32 \mathrm{bp}$ double-stranded oligonucleotide of unrelated sequence (CACAGTAGCCTCCAACCTTGGAGATTCAAGTG) (Fig. 6, lanes $1-3)$, demonstrating that the binding observed was specific. Thus $M$. tuberculosis LexA recognizes and binds to a Cheo-box-type motif.

\section{DISCUSSION}

The gene coding for the M. tuberculosis homologue of LexA has been cloned and sequenced. Its protein product shows significant homology to other LexA proteins, and a more detailed comparison with the $E$. coli sequence, for which the roles of particular residues have been identified, is informative with regard to its probable mode of action. The cleavage site of E. coli LexA is between Ala-84 and Gly-85 (Horii et al., 1981a) and the nucleophile in this reaction has been identified as Ser119 , with Lys-156 also being required as an activator 


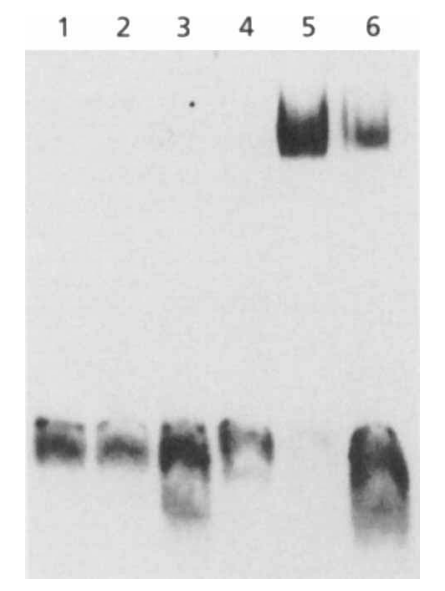

Fig. 6. $M$. tuberculosis LexA binds to its own Cheo box. Gel retardation analysis using a $32 \mathrm{bp}$ double-stranded oligonucleotide of random sequence (lanes 1-3) or the sequence spanning the Cheo box found upstream of lexA (lanes 4-6) with: no protein added (lanes 1 and 4); $0.1 \mu \mathrm{g}$ LexA added (lanes 2 and 5); $0.1 \mu \mathrm{g}$ LexA plus $7.6 \mathrm{pmol}$ unlabelled oligonucleotide of the same sequence added (lanes 3 and 6).

(Slilaty \& Little, 1987); these residues are identical and their flanking amino acids are also conserved in all LexA proteins sequenced (Garriga et al., 1992; Horii et al., 1981b; Markham et al., 1981; Mustard et al., 1992; Raymond-Denise \& Guillen, 1991; Riera \& Barbe, 1993, 1995; accession numbers P44858 and U00019, position 7772), including that of $M$. tuberculosis presented here, suggesting a common mechanism of proteolytic cleavage.

In contrast, the amino acids important for specific DNA binding in E. coli LexA are not conserved in $M$. tuberculosis LexA; this is not surprising because $M$. tuberculosis LexA binds to a different DNA sequence to that of E. coli. The particular amino acids Asn-41, Glu44 and Glu-45 in E. coli LexA are predicted to form specific $\mathrm{H}$-bonds and Ser-39 and $\mathrm{Ala}-42$ are predicted to form specific hydrophobic interactions with the CTGT bases in its recognition site, according to a model of the LexA DNA complex (Knegtel et al., 1995) based on the structure of the LexA DNA-binding domain (Fogh et al., 1994) in which a helix-turn-helix motif was identified spanning residues $28-52$. The importance of these five amino acids is supported by mutational studies (Thliveris et al., 1991; Thliveris \& Mount, 1992) and they, along with the flanking residues, are absolutely conserved amongst eight Gram-negative LexA sequences (Garriga et al., 1992; Horii et al., 1981b; Markham et al., 1981; Mustard et al., 1992; Riera \& Barbe, 1993, 1995; accession number P44858); however, only one of them, the serine residue, is found in $M$. tuberculosis LexA or indeed LexA from M. leprae or $B$. subtilis, the other Gram-positive LexA proteins for which the sequence is known. Since these three Grampositive LexA proteins appear to all bind to the same recognition sequence, it might be expected that they would share an equivalent highly conserved amino acid motif, but if this is so, it is not in the same location in the sequence. There is, however, a high degree of conservation apparent amongst the three Gram-positive sequences for the region from residue 27 to 41 (numbering the $M$. tuberculosis sequence), which is predicted to be alpha helical by the Eisenberg algorithm, and it may be that in these cases, if an analogous helix-turn-helix motif exists, it is displaced relative to its location in the E. coli LexA protein. In addition, the difference in the number of bases between the palindromic conserved four base sequence in each motif (eight in E. coli and four in M. tuberculosis) implies that the two recognition helices in the LexA dimers from these organisms are arranged differently in terms of separation or orientation (Suzuki et al., 1995). Studies to address these questions are in progress.

Expression and purification of the M. tuberculosis LexA protein has been achieved using E. coli, and this has allowed us to demonstrate that it recognizes and binds to the same motif as that found upstream of SOSinducible genes in B. subtilis known as a Cheo box. Curiously, two additional copies of this motif separated by only $7 \mathrm{bp}$ are located further upstream of the $M$. leprae lex $A$ gene, being 284 bp and 265 bp, respectively, before the coding sequence. Each of these copies has only a single mismatch from the B. subtilis consensus, suggesting that they are equally likely to be functional as the motif closer to the gene; it will be interesting to determine whether there are also multiple copies of the motif in M. tuberculosis and what role they play in regulation of LexA expression. There are also three copies of the Cheo box upstream of the B. subtilis lexA gene, but more evenly spaced. It is pertinent to note that the Gram-negative species which have been studied possess two binding sites for LexA separated by only 3-5 bp upstream of their lexA genes, but in these cases the operators overlap the promoters and are very close to the beginning of the genes (Brent \& Ptashne, 1981; Garriga et al., 1992; Riera \& Barbe, 1993, 1995). It has been shown that in $E$. coli, LexA protein binds to each of these multiple sites with lower affinity than it does to the single binding site upstream of the recA gene (Brent \& Ptashne, 1981). The presence of multiple binding sites for LexA might allow a more subtle level of regulation than would be possible with a single site, perhaps with different degrees of expression correlating with different levels of occupancy of the sites. Similarly, varying affinities of LexA for different promoters will result in variable timing of their induction, presumably reflecting their individual roles in DNA repair and cell survival. Additionally, where the separation of the individual motifs is more than just a few base pairs as in B. subtilis, it has been proposed that the formation of a regulatory loop involving cooperative binding of LexA might occur (Cheo et al., 1991).

These results indicate that $M$. tuberculosis LexA recognizes and binds to a similar sequence to that of $B$. subtilis (GAAC- $\mathrm{N}_{4}$-GTTC), another Gram-positive bacterium, but which is quite unlike the SOS box to which LexA binds in many Gram-negative bacteria 
(CTGT- $\left.\mathrm{N}_{8}-A C A G\right)$. This is only the second species documented to use this 'Cheo' box for LexA binding, and may be indicative of a general trend amongst Grampositive bacteria. If this is the case, it would imply that the sequence to which LexA binds, together with the LexA protein itself, have evolved separately after the division into Gram-positive and Gram-negative bacteria. The difference in the number of bases between the palindromic conserved four base sequence in each motif must also imply differences in the arrangement of the two recognition helices in the LexA dimers and hence in their overall quaternary structures.

These studies will now facilitate the elucidation of the role of LexA in the regulation of DNA-damage-inducible genes and particularly $r e c A$ in mycobacteria. It may be envisaged that, analogous to other LexA-regulated systems, the binding of LexA to its recognition site upstream of the genes it regulates would repress transcription. Upon DNA damage RecA would be activated, leading to cleavage of LexA, release of the LexA fragments from the binding site and, hence, expression of the gene concerned.

\section{ACKNOWLEDGEMENTS}

We are very grateful to Stewart Cole for providing the cosmid T616 and the M. tuberculosis lexA probe. We would also like to thank Peter Jenner for help with the protein purification, K. Papavinasasundaram for helpful discussions and Patricia Brooks for technical advice. F.M. is supported by a research training grant from the UNDP/World Bank/WHO Special Programme for Training in Tropical Diseases.

\section{REFERENCES}

Brent, R. \& Ptashne, M. (1981). Mechanism of action of the lexA gene product. Proc Natl Acad Sci USA 78, $4204-4208$.

Cheo, D. L., Bayles, K. W. \& Yasbin, R. E. (1991). Cloning and characterisation of DNA damage inducible promoter regions from Bacillus subtilis. J Bacteriol 173, 1696-1703.

Davis, E. O., Sedgwick, S. G. \& Colston, M. J. (1991). Novel structure of the recA locus of Mycobacterium tuberculosis implies processing of the gene product. J Bacteriol 173, 5653-5662.

Davis, E. O., Thangaraj, H. S., Brooks, P. C. \& Colston, M. J. (1994). Evidence of selection for protein introns in the RecAs of pathogenic mycobacteria. EMBO J 13, 699-703.

Devereux, J., Haeberli, P. \& Smithies, O. (1984). A comprehensive set of sequence analysis programs for the VAX. Nucleic Acids Res 12, 387-395.

Fogh, R. H., Ottleben, G., Ruterjans, H., Schnarr, M., Boelens, R. \& Kaptein, R. (1994). Solution structure of the LexA repressor DNA binding domain determined by $\mathrm{H}^{+}$NMR spectroscopy. EMBO J 13, 3936-3944.

Garriga, X., Calero, S. \& Barbe, J. (1992). Nucleotide sequence analysis and comparison of the lexA genes from Salmonella typhimurium, Erwinia carotovora, Pseudomonas aeruginosa and Pseudomonas putida. Mol Gen Genet 236, 125-134.

Gonzalez-y-Merchand, J. A., Colston, M. J. \& Cox, R. A. (1996). The rRNA operons of Mycobacterium smegmatis and Mycobacterium tuberculosis: comparison of promoter elements and of neighbouring upstream genes. Microbiology 142, 667-674.
Holmes, D. S. \& Quigley, M. (1981). A rapid boiling method for the preparation of bacterial plasmids. Anal Biochem 114, 193-197.

Horii, T., Ogawa, T., Nakatani, T., Hase, T., Matsubara, H. \& Ogawa, H. (1981a). Regulation of SOS functions: purification of E. coli LexA protein and determination of its specific site cleaved by the RecA protein. Cell 27, 515-522.

Horii, T., Ogawa, T. \& Ogawa, H. (1981b). Nucleotide sequence of the lexA gene of E. coli. Cell 23, 689-697.

Knegtel, R. M. A., Fogh, R. H., Ottleben, G., Ruterjans, H., Dumoulin, P., Schnarr, M., Boelens, R. \& Kaptein, R. (1995). A model for the LexA repressor DNA complex. Proteins 21, 226-236.

Kochi, A. (1991). The global tuberculosis situation and the new control strategy of the World Health Organisation. Tubercle 72 , $1-6$.

Little, J. W. (1984). Autodigestion of lexA and phage lambda repressors. Proc Natl Acad Sci USA 81, 1375-1379.

Little, J.W. (1991). Mechanism of specific LexA cleavage: autodigestion and the role of RecA coprotease. Biochimie 73, $411-422$

Little, J. W. \& Mount, D. W. (1982). The SOS regulatory system of Escherichia coli. Cell 29, 11-22.

Little, J. W., Kim, B., Roland, K. L., Smith, M. H., Lin, L. L. \& Slilaty, S. N. (1994). Cleavage of LexA repressor. Methods Enzymol 244, 266-284.

Markham, B. E., Little, J. W. \& Mount, D. (1981). Nucleotide sequence of the lexA gene of Escherichia coli K-12. Nucleic Acids Res 9, 4149-4161.

Mead, D. A., Szczesna-Skorupa, E. \& Kemper, B. (1987). Singlestranded DNA 'blue' T7 promoter plasmids: a versatile tandem promoter system for cloning and protein engineering. Protein Eng $1,67-74$.

Miller, R. V. \& Kokjohn, T. A. (1990). General microbiology of recA: environmental and evolutionary significance. Annu Rev Microbiol 44, 365-394.

Mustard, J. A., Thliveris, A. T. \& Mount, D. W. (1992). Sequence of the Salmonella typhimurium LT2 lexA gene and its regulatory region. Nucleic Acids Res 20, 1813.

Philipp, W. J., Poulet, S., Eiglmeier, K., Pascopella, L., Balasubramanian, V., Heym, B., Bergh, S., Bloom, B. R., Jacobs, W. R. \& Cole, S. T. (1996). An integrated map of the genome of the tubercle bacillus, Mycobacterium tuberculosis H37Rv, and comparison with Mycobacterium leprae. Proc Natl Acad Sci USA 93, 3132-3137.

Raymond-Denise, A. \& Guillen, N. (1991). Identification of dinR, a DNA damage-inducible regulator gene of Bacillus subtilis. $J$ Bacteriol 173, 7084-7091.

Riera, J. \& Barbe, J. (1993). Sequence of the Providencia rettgeri lexA gene and its control region. Nucleic Acids Res 21, 2256.

Riera, J. \& Barbe, J. (1995). Cloning, sequence and regulation of expression of the lexA gene of Aeromonas bydrophila. Gene 154, 71-75.

Rosenberg, M. \& Court, D. (1979). Regulatory sequences involved in the promotion and termination of RNA transcription. Annu Rev Genet 13, 319-353.

Sambrook, J., Fritsch, E. F. \& Maniatis, T. (1989). Molecular Cloning : a Laboratory Manual, 2nd edn. Cold Spring Harbor, NY: Cold Spring Harbor Laboratory.

Sarkis, G. J., Jacobs, W. R. \& Hatfull, G. F. (1995). L5 luciferase reporter mycobacteriophages: a sensitive tool for the detection and assay of live mycobacteria. Mol Microbiol 15, 1055-1067. 
Slilaty, S. N. \& Little, J. W. (1987). Lysine-156 and serine-119 are required for LexA repressor cleavage: a possible mechanism. Proc Natl Acad Sci USA 84, 3987-3991.

Studier, F. W., Rosenberg, A. H., Dunn, J. J. \& Dubendorff, J. W. (1990). Use of T7 RNA polymerase to direct expression of cloned genes. Methods Enzymol 185, 60-89.

Suzuki, M., Yagi, N. \& Gerstein, M. (1995). DNA recognition and superstructure formation by helix-turn-helix proteins. Protein Eng 8, 329-338.

Thliveris, A. T. \& Mount, D. W. (1992). Genetic identification of the DNA binding domain of Escherichia coli LexA protein. Proc Natl Acad Sci USA 89, 4500-4504.

Thliveris, A. T., Little, J. W. \& Mount, D. W. (1991). Represssion of the E. coli recA gene requires at least two LexA protein monomers. Biochimie 73, 449-455.
Timm, J., Perilli, M. G., Duez, C., Trias, J., Orefici, G., Fattorini, L., Amicosante, G., Oratore, A., Joris, B., Frere, J. M., Pugsley, A. P. \& Gicquel, B. (1994). Transcription and expression analysis, using lac $Z$ and phoA gene fusions, of Mycobacterium fortuitum $\beta$-lactamase genes cloned from a natural isolate and a high-level $\beta$-lactamase producer. Mol Microbiol 12, 491-504.

Walker, G. C. (1984). Mutagenesis and inducible responses to deoxyribonucleic acid damage in E. coli. Microbiol Rev 48, 60-93.

Yanisch-Perron, C., Vieira, J. \& Messing, J. (1985). Improved M13 phage cloning vectors and host strains: nucleotide sequences of the M13mp18 and pUC19 vectors. Gene 33, 103-119.

Received 20 June 1996; revised 19 September 1996; accepted 26 September 1996. 